\title{
Model dan Pola Computer Mediated Communication Pengguna Remaja Instagram dan Pembentukan Budaya Visual
}

\author{
Edwi Arief Sosiawan dan Rudi Wibowo \\ Fakultas Ilmu Sosial dan Ilmu Politik UPN Veteran Yogyakarta \\ Email: edwias@upnyk.ac.id \\ Email: rudi_ruri@yahoo.com
}

\begin{abstract}
Social media use is a part of computer mediated communication pattern which it was a form of communication mediated by computer networking. This technology then was convergence with smartphone. Teenagers as digital native and variety seeker were the most of social media use among others who use instagram. They migrate from social media which it did not focus on visual presentation to visual concerns when they interact to others. These have deconstructed from verbal style message to visual message. This research investigated to how teenagers as individuals who have autonomy deconstructed their own acts from verbal message communication to visual message communication as a culture within virtual space. Method that was used was nataralistic ethnography that was intended to get fruitful information from informants. The result and conclusion exposed that teenagers who use instagram to visualize their message communication for self presentation at any moment and situations.
\end{abstract}

Keywords: Message visual communication, CMC, Instagram, Teenagers, Social Media

\begin{abstract}
Abstrak
Penggunaan media sosial merupakan bagian pola computer mediated communication (CMC) yang dimediasi jaringan internet. Teknologi ini berkonvergensi dengan media mobile berupa smartphone. Remaja sebagai digital native dan variety seeker merupakan pengguna terbanyak instagram. Remaja bermigrasi dari media sosial yang sebelumnya tidak terfokus pada pesan visual ke dalam pesan visual ketika berhubungan dengan komunikan lain dalam jejaring sosial. Pola CMC remaja melalui Instagram mendekontruksi komunikasi verbal menjadi komunikasi visual. Penelitian melihat bagaimana remaja mendekontruksi pesan verbal ke dalam pesan visual yang membentuk budaya visual dalam ruang virtual. Metode yang digunakan naturalistik etnografi untuk mendapatkan informasi yang kaya. Kesimpulan yang diperoleh budaya visual remaja melalui instagram merupakan upaya remaja menvisualisasikan eksistensi identitas diri mereka dalam konteks moment dan kesenangan tertentu.
\end{abstract}

Kata Kunci: CMC, Remaja, Media Sosial, Budaya Visual, Instagram 


\section{Pendahuluan}

Pada awalnya media sosial diaplikasikan dalam bentuk pemakaian personal computer namun seiring melajunya konvergensi teknologi, media sosial telah terintegrasi dengan teknologi telepon seluler (ponsel) dalam bentuk smartphone. Aplikasi media sosial yang mobile ini memudahkan para penggunanya untuk berkomunikasi dan berinteraksi tanpa harus terpaku di depan komputer, oleh karenanya media sosial semakin populer dalam penggunaanya untuk berkomunikasi dan bersosialisasi.

Pada tahun 2014 survey dari AC Nielsen menyebutkan bahwa pengguna Instagram semakin meningkat meninggalkan Facebook dan Twitter. Instagram menduduki peringkat yang lebih tinggi dibanding Twitter dalam 10 aplikasi terpopuler. Instagram dilihat sebanyak 32 juta orang perbulan sedangkan Twitter sebanyak 30,8 juta orang perbulan (http://www.republika. co.id/berita/trendtek/aplikasi/14/01/01/mypdh6instagram-bakal-geser-posisi-twitter 1 januari 2015 diakses tangal 12 Maret 2015).

Instagram adalah aplikasi jejaring sosial berbasis picture publishing and sharing yang memungkinkan pengguna mengambil foto, menerapkan filter digital, dan membagikannya ke berbagai layanan jejaring sosial. Berbeda dengan Facebook dan Twitter, Instagram menggunakan foto dan video sebagai pesan yang dapat dibaca sebagai sebuah teks. Platform penggunaan Instagram merujuk pada penggunaan media mobile (smartphone) untuk mengunggah foto secara spontan yang berbentuk snapshot atau foto instan langsung dibagikan ke pada user lain.

Salah satu kelompok yang bergantung dan menyukai penggunaan media sosial serta menjadi pengguna terbanyak adalah golongan remaja (adolscene). Kompas dalam artikelnya bulan Januari 2014 menyebutkan remaja menjadi pengguna terbanyak media sosial karena mereka adalah generasi Z(lahir 1995-2005) yaitu generasi era booming konvergensi media Information and communication technologie (ICT). Hasil survei Frontier Consulting Group Indonesia yang dikutip kompas tersebut menyebutkan perilaku digital remaja Indonesia menunjukkan adanya peningkatan drastis pada perilaku digital remaja hanya dalam kurun waktu satu tahun saja.

Golongan remaja lebih familiar serta memiliki intensitas yang tinggi dalam menggunakan media sosial dikarenakan mereka merupakan generasi digital native yaitu generasi yang lahir dan hidup pada perkembangan teknologi digital internet. Oleh karenanya remaja menggunakan media sosial untuk dapat mendokumentasikan setiap aspek kehidupannya melalui berbagai fitur serta fasilitas di dalamnya mulai dari kemudahan berbagi foto dan video, memberitahukan lokasi serta kebutuhan primer mereka berupa percakapan pribadi disertai dengan berbagai macam emoticon.

Remaja sebagai pengguna media sosial secara psikologis memiliki karakteristik variety seeker (Green, 2005), karakter yang cepat bosan dan selalu mencoba hal baru karena keresahan akan identitasnya. Remaja selalu mencoba hal-hal baru meskipun relatif cepat bosan dan tidak fokus namun justru kuat dalam ikatan dengan kelompok asosiasinya. Remaja cenderung memiliki pengaruh dan terpengaruh perilaku dan keyakinan kelompoknya. Oleh karenanya unsur konformitas menjadi hal utama dalam penggunaan media sosial agar tetap eksis dalam kelompoknya.

Dinamisasi perubahan perilaku remaja dalam penggunaan media sosial tersebut disamping mengikuti trend dan popularitas juga mengikuti perubahan gaya dan karakteristik media sosial itu sendiri. Karakteristik Facebook kini semakin tenggelam penggunaannya di kalangan remaja akibat kehadiran Twitter yang membatasi pesan hanya 140 karakter. Twitter mereduksi pengguna remaja Facebook yang semula 94 prosen di tahun 2013 menjadi 88 prosen di tahun 2014. Facebook dianggap tidak menarik lagi karena banyak orang bergabung di Facebook sehingga tidak lagi elit/prestise, apalagi semakin banyak konten di dalam Facebook yang tidak relevan seperti konten promosi, iklan serta tawaran game yang dianggap mengganggu oleh pengguna budaya visual yang dilakukan 
remaja melalui unggahan foto dalam Instagram merupakan upaya remaja menvisualisasikan keberadaan/eksistensi identitas diri mereka dalam konteks moment tertentu dan kesenangan tertentu.remaja (http://sp.beritasatu.com/inovasi/ popularitas-facebook-kian-meredup/72551 tgl 22 Desember 2014).

Karateristik Instagram yang berbeda dengan memberi kesempatan pengguna berekspresi menggunakan foto dalam jejaring sosial juga mengurangi pengguna twitter di kalangan remaja. Fenomena penggunaan Instagram sebagai media komunikasi mereduksi kata dan simbol verbal menjadi perilaku memotret fenomena menjadi foto. Ini merupakan hal kedua yang menonjol dari maraknya remaja menggunakan Instagram yaitu bahwa simbol foto sudah mewakili apa yang sedang dirasakan, dilihat dan yang akan dikatakan. Simbol yang semula verbal terbatas pada space tidak lagi diperlukan. Sedangkan pada sisi lain pesan foto yang terpampang di Facebook tidak fokus pada pesan yang diinginkan sehingga tidak menjadi lebih menarik daripada pesan verbal yang disampaikan.

Peningkatan penggunaan Instagram di kalangan remaja secara komunikasi mengarah pada dekonstruksi pesan verbal dari media sosial populer sebelumnya seperti Facebook, Twitter dan Myspace menjadi pesan-pesan bersifat gambar atau foto. Fenomena dekontruksi pesan verbal tersebut berada dalam perilaku penggunaan Instagram berupa mengunggah foto, memberikan filter pada hasil foto, melakukan following dan unfollow, memberikan like dan komentar foto yang ada pada jaringan sosial, serta membubuhi informasi pada foto.

Remaja dalam penggunaan Instagram untuk berkomunikasi melalui media mobile (smartphone) mengukuhkan bahwa terdapat nilai-nilai, norma-norma serta keyakinan dalam diri remaja dalam unggahan foto mereka yang cenderung membentuk pola budaya visual (visual culture) dengan mendekontruksi komunikasi verbal. Dalam konteks yang lain perilaku komunikasi menggunakan Instagram juga menjadi ajang penyebarluasan budaya visual, dalam hal tersebut Martin dan Nakayama (2003:97-99) menegaskan bahwa budaya tidak akan bisa terbentuk tanpa komunikasi sedangkan pola-pola komunikasi yang tentunya sesuai dengan latar belakang dan nilai-nilai budaya akan menggambarkan identitas budaya seseorang.

Keterikatan timbal balik (reciprocal) antara budaya visual dan komunikasi menggunakan media sosial Instagram inilah menjadi dasar asumsi bahwa dalam CMC melalui media sosial Instagram akan mampu membentuk budaya visual di kalangan remaja sementara budaya visual itu sendiri akan berpengaruh pada cara berkomunikasi remaja yang bersifat simulasi dan hiperealitas karena bentuk budaya apapun akan membentuk persepsi seseorang terhadap suatu realitas. Oleh karena itu dalam penelitian ini mengambil rumusan masalah "Bagaimana pola CMC yang dilakukan remaja melalui media sosial Instagram mendekontruksi komunikasi verbal menjadi komunikasi visual dalam pembentukan budaya visual oleh remaja melalui ruang simulasi dan hiperealitas dalam Instagram ?"

Secara teknis CMC merupakan bentuk penggunaan berbagai jenis program aplikasi yang digunakan untuk melakukan komunikasi antar dua orang atau lebih dan dapat saling berinteraksi melalui komputer yang berbeda tanpa terkendala jarak, ruang dan waktu, seperti yang disampaikan Herring (1996) dalam Thurlow $(15,2007)$; "computer-mediated discourse is the communication produced when human beings interact with one another by transmitting messages via networked computers".

Secara faktual dunia proses komunikasi yang berlangsung melalui CMC adalah berada pada wilayah cyberspace (secara teknis merupakan aplikasi komunikasi melalui internet berupa jaringan besar yang menggunakan protocols untuk melakukan transfer data). Cyberspace adalah ruang mutlak terjadinya CMC sehingga secara "virtual" manusia sebenarnya berada pada ruang tersebut meskipun secara "wujud" berada pada ruang/alam nyata ( real world).

Cyberspace ( ruang siber) sebagai ruang 
mutlak CMC sebenarnya merupakan istilah yang berasal dari novel William Gibson yang berjudul Neuromancer tahun 1984, dalam novel tersebut disebutkan bahwa cyberspace adalah halusinasi konsensual yang dialami oleh manusia sebagai bagian dari representasi kompleksitas grafis dari data yang digunakan manusia dalam sistem komputer (Bell, 2, 2007). Oleh karenanya kemudian dianggap bahwa cyberspace (ruang maya) bersifat "paralel" dengan dunia nyata yang oleh Benedikt dalam Bell (16:2007) dinyatakan bahwa cyberspace : the tablet become a page become a screen become a world, a virtual world. Everywhere and nowhere, a place where nothing is forgotten and yet everything changes.

Dengan demikian CMC terjadi dalam ruang baku cyberspace yang merupakan sebuah metafora untuk menggambarkan medan nonfisik yang dibuat oleh sistem komputer. Seperti ruang fisik, dunia maya berisi objek (file, pesan email, grafis, dan sebagainya ) dan berbagai mode transportasi dan pengiriman. Perbedaan pergerakan yang terjadi dalam dunia maya adalah tidak memerlukan gerakan fisik selain menekan tombol pada keyboard atau menggerakkan mouse. Meskipun terdapat perbedaan diantara real world dan cyberspace namun dua dunia tersebut sudah overlapping dalam kehidupan manusia seperti telah dinyatakan oleh Benedikt di atas. Sehingga dapat dikatakan bahwa sejak penggunaan ruang siber sebagai ruang berkomunikasi maka CMC sudah memasuki era sebagai perilaku komunikasi yang inevitable (tak terelakan).

Terdapat tiga kategori teori besar dalam pendekatan teori CMC yang meliputi kategori sebagai berikut ; Pertama, Cues-FilteredOut Theories ; Teori Penyaring Petunjuk ini menggambarkan sekelompok premis yang menyatakan bahwa CMC tidak memiliki isyarat nonverbal, oleh karena itu maka $\mathrm{CMC}$ menyumbat pemenuhan fungsi sosial yang biasanya melibatkan isyarat nonverbal tersebut sehingga maka hanya sedikit ikatan sosial-emosi yang terbentuk secara online melalui CMC (Walther, 385, 2009). CMC yang menggunakan ruang siber yang tak berwujud memiliki kelemahan yaitu para pengguna tidak dapat menggunakan gerak tubuh, nada suara dan ekspresi raut wajah. Lebih jauh lagi CMC kurang memiliki norma dan standar sosial yang bersifat similar sehingga mendorong pengguna menjadi lebih agresif dan impulsif. Meskipun CMC tidak mampu dalam memberikan petunjuk sosialemosi namun CMC lebih mendemokrasikan hubungan antar manusia.

Menurut teori penyaring petunjuk, CMC memiliki dampak sosial yang signifikan terhadap hierarki organisasional. Pada interaksi langsung (face to face), ada korelasi yang kuat antara hierarki sosial dan jumlah partisipasi pada suatu event dan kondisi tertentu, namun melalui CMC maka hubungan hierarkhi tersebut menjadi hilang. Teori - teori yang turut mendukung premis kategori ini adalah sebagai berikut : a). Social Presence Theory ; atau teori kehadiran Sosial yang di kemukakan oleh Shorth, Williams, \& Cristie pada tahun 1976 menyatakan bahwa masing - masing media memunculkan perbedaan derajat penerimaan substansi pesan dalam sebuah interaksi (Joseph B. Walther dalam Knapp, 445, 2010). b). Lack of Social Context Cues ; masih sejalan dengan teori di atas bahwa dalam proses CMC terjadi sumbatan isyarat individualitas dan perilaku normatif tentang interaksi face-to-face yang juga bertransaksi secara nonverbal. Akibatnya, partisipan CMC menjadi deindividuated (tidak menjadi dirinya) dan berkurang rasa norma sosialnya. c) Media Richness; atau teori kesempurnaan media Istilah ini sering digunakan dalam berbagai literatur untuk menandakan media yang multimodal atau media komunikasi yang mendukung beberapa sistem isyarat verbal dan nonverbal. d) The Social Identity Model of Deindividuation Effects ; . (Model SIDE) SIDE adalah salah satu prespektif teori yang paling dominan dalam CMC yang menjelaskan bagaimana perilaku kelompok dipengaruhi oleh anonimitas dan identifiability (Joseph B. Walther dalam Knapp, 450, 2010). e). Signaling Theory; Prespektif dari teori ini menekankan bahwa dalam proses CMC 
memperlihatkan terjadinya legitimasi terhadap orang lain dari presentasi dirinya secara online serta cara CMC memfasilitasi presentasi tersebut.

Budaya visual adalah salah satu wujud kebudayaan konsep (nilai) dan kebudayaan materi (benda) yang dapat segera ditangkap oleh indera visual (mata) serta dapat dipahami sebagai tautan pikiran manusia untuk meningkatkan kualitas hidupnya. Dalam pemahaman Mirzoeff budaya visual atau visual culture merujuk kepada peristiwa visual yang informasi, makna atau kesenangan dicari oleh pengguna ketika terhubung dengan teknologi visual (Mirzoeff, 3, 1998). Visual yang dimaksud disini oleh Mirzoeff adalah segala bentuk aparatus yang didesain termasuk yang diperlihatkan atau ditambahkan dalam bentuk alami dari lukisan minyak, produk televisi dan internet. Sedangkan menurut De Certau (1984 : 37) budaya visual adalah : “ Description of everyday life, visual culture is a tactic, for " the place of the tactic belongs to the order ". A tactic is carried out in full view of the enemy, the society of control in which we live. ( budaya visual merupakan sebuah taktik untuk melakukan suatu perlawanan terhadap budaya yang telah ada).

Namun, budaya visual bukan sebatas menangkap kejadian nyata ke dalam media visual. Mirzoeff menyatakan salah satu fitur dari kebudayaan visual adalah 'visualisasi dari suatu yang tidak visual'. Budaya visual tidak bergantung pada gambar semata, namun kecenderungan untuk menggambarkan atau memvisualisasikan keberadaan (Mirzoeff 2002: 6). Dengan kata lain budaya visual adalah suatu yang dapat "memvisualisasikan" sesuatu, baik itu sesuatu yang tampak maupun tidak tampak. Pemahaman ini didasarkan pada konsep Heidegger (1977) "The world picture does not change from an earlier medieval one into a modern one, but rather the fact that the world becomes picture at all is what distinguishes the essence of the modern age". Budaya visual tidak tergantung pada gambar atau bentuk visual itu sendiri, tetapi dalam konsep modern merupakan kecenderungan untuk memvisualisasikan suatu keberadaan (eksistensi). Visualisasi tersebut menjadikan budaya visual masa modern sangat berbeda dari budaya visual abad pertengahan dengan cirinya yang bersifat umum dan dilakukan oleh kebanyakan manusia.

François Quesnay (Mirzoeff, 2002, 7) mengungkapkan prinsip visualisasi secara umum tidak menggantikan wacana tetapi membuatnya lebih dipahami, lebih cepat dan lebih efektif. Visualisasi memiliki efek paling dramatis dalam berbagai bidang mulai dari bidang medis, bidang komputer yang telah menghasilkan rasa baru kegembiraan serta upaya besar dalam memvisualisasi. Budaya visual memfokuskan pada bentuk visual sebagai tempat diciptakan dan diperebutkan. Budaya barat telah secara konsisten menempatkan sebagai bentuk tertinggi dari praktek intelektual dan melihat representasi visual merupakan ilustrasi kedua tingkat ide. Dalam pandangan Mitchell, teori gambar berasal dari "kesadaran bahwa spectatorship (tampilan, tatapan, sekilas, praktik observasi, pengawasan, dan kesenangan visual) lebih bermakna dalam karena berbagai bentuk membaca (penguraian, decoding, interpretasi, dan lain-lain) tidak lebih baik dari pengalaman visual 'atau' literasi visual 'yang tidak sepenuhnya dapat dijelaskan dalam model tekstualitas "(Mitchell 1994: 16).

Kebanyakan ahli teori postmodern menyepakati bahwa salah satu fitur khas era posmodern adalah dominasi visual. Kemunculan virtual reality dan Internet serta dikombinasikan dengan popularitas televisi, rekaman video dan film menyebabkan tren budaya visual ini tampaknya akan terus berlanjut. Salah satu tugas pokok budaya visual adalah untuk memahami bagaimana gambar yang kompleks datang bersama-sama. Mereka tidak diciptakan dari satu medium atau satu tempat tetapi mengarahkan perhatian menjauh dari hal yang terstruktur seperti tampilan formal bioskop dan galeri seni sebagai sentralitas pengalaman visual dalam kehidupan sehari-hari. Namun, pengalaman visual terjadi selain pada saat-saat formal terstruktur mencari tetapi juga meliputi hal-hal yang tak berstruktur dan tak formal. 


\section{Metode Penelitian}

Penelitian ini menggunakan pendekatan konstruktitivis - interpretatif berdasar pada asumsi realitas yang beragam yang bersifat subjektif dengan sifat naturalistik apa adanya. Metode penelitian yang digunakan adalah eksplorasi - etnografi. Penelitian ekploratif dimaksudkan untuk melukiskan secara sistematis fakta atau karakteristik populasi tertentu secara faktual dan cermat. Sifat penelitian eksploratif yang deskriptif menitikberatkan pada suasana alamiah yang memaparkan situasi atau peristiwa.( Rakhmat, 45, 1999 ). Sedangkan metode etnografi merupakan metode yang biasa digunakan dalam etnografi, melingkupi wawancara, maupun pengalaman pribadi. Melalui metode etnografi akan dapat terungkap komitmen untuk menjadi lebih 'jujur' terhadap kehidupan masyarakat (Sauko, 2003:56).

Subjek dalam penelitian ini adalah remaja awal dan akhiryaitu mereka yang berada pada usia 16 tahun hingga 18 tahun sebagai digital native yang lebih banyak menggunakan media sosial Instagram dan menjadi perhitungan tersendiri agar dicapai kedalaman dalam penelitian ini. Dalam menganalisis penelitian terlebih dahulu akan melakukan klasifikasi, diverifikasi dan diinterpretasikan. Analisis ini pada prinsipnya bertujuan untuk menyederhanakan sekaligus menjelaskan bagian-bagian dari keseluruhan data melalui langkah-langkah klasifikasi dan kategorisasi sehingga tersusun rangkaian deskripsi yang sistematis. Pengujian validitas data dilakukan dengan teknik triangulasi, yaitu pengujian meminta sumber lain sebagai pembanding untuk lebih meyakinkan pernyataan yang ada. Pengujian ini dilakukan melalui diskusi dengan para ahli culture studies, komunikasi sosial dan ahli psikologi.

\section{Hasil Penelitian dan Pembahasan}

Penelitian ini menggunakan tradisi penelitianparadigmakualitatifdenganpendekatan etnografi sebagai upaya penggambaran (mendeskripsikan) suatu budaya atau cara hidup orang-orang dalam sebuah komunitas tertentu yang dimaknai sebagai penulisan artifak budaya. Pendekatan etnografi digunakan untuk lebih melihat aktivitas subjek penelitian yang nyata namun berada pada dunia virtual. Oleh karena itu untuk lebih memudahkan dalam perolehan data penelitian yang akurat maka penelitian ini menggunakan pendekatan etnografi yang bersifat virtual atau dapat dikatakan netnografi.

Secara prosedural alur penelitian etnorafi virtual dalam penelitian ini menggunatkan prosedural penelitian etnografi yang dikembangkan oleh Spradley (2016). Sebagaimana sebuah penelitian etnografi yang mengedepankan naturalistik dalam mendapatkan data yang bersifat deskriptif, maka penelitian ini memanfaatkan teknik pengumpulan melalui dua instrumen pengumpulan data kualitatif khas dan primer dalam etnografi virtual

Informan dalam penelitian ini adalah remaja yang bisa menjawab tentang posisi mereka sebagai remaja dan juga mereka yang bisa menjelaskan pertanyaan dari peneliti terkait dengan kontribusi mereka dalam melakukan aktivitas melalui media sosial Instagram. Para informan dalam penelitian ini adalah mereka remaja usia 16 tahun hingga 18 tahun, yaitu remaja awal dan remaja akhir. Pemilihan subjek penelitian adalah remaja menjadi pertimbangan tersendiri mengingat remaja adalah mereka yang lahir setelah tahun 1996 yaitu mereka yang sering disebut sebagai digital natives atau net generation, suatu generasi yang lahir setelah adanya teknologi internet. Subjek penelitian remaja lebih fasih dan berkompeten dalam menggunakan media sosial Instagram serta secara statistik adalah pengguna terbanyak dalam penggunaan Instagram.

Penelitian ini memadukan antara hasil wawancara dengan konten atau isi foto yang digunakan sebagai ekspresibudaya visual mereka. Melalui foto yang diunggah subjek penelitian akan dianalisis menggunakan pendekatan analisi isi agar di dapatkan kecenderungan subjek penelitian dalam menyampaikan pesan-pesan dalam bentuk foto sebagai simbol yang mereka gunakan. 
Melihat perilaku penggunaan instagram oleh subjek penelitian maka dapat di lihat dalam beberapa aspek seperti lama mengenal dan menggunakan media sosial Instagram, durasi menggunakan Instagram, jenis foto yang diposting serta alasan memposting fotofoto yang ada dalam akun Instagram subjek penelitian. Dari 30 subjek penelitian didapatkan fakta-fakta mengenal dan penggunaan media sosial Instagram sebagai berikut :
Kebutuhan berkomunikasi dan berinteraksi menggunakan telepon seluler tentunya tidak bisa diabaikan dari kehidupan remaja. Penggunaan ponsel sebagai media komunikasi telah menjadi gaya hidup masyarakat termasuk remaja sehingga penyebaran media sosial Instagram tidak bisa diabaikan. Pada sisi lain adanya kebutuhan akan eksistensi diri melalui interaksi dan komunikasi juga semakin meningkat seiring perkembangan psikis dan aktivitas yang dibutuhkan oleh

Tabel 1.

Penggunaan Media Sosial Instagram

\begin{tabular}{|l|l|r|r|}
\hline NO & \multicolumn{1}{|c|}{$\begin{array}{c}\text { LAMA KEPEMILIKAN } \\
\text { AKUN }\end{array}$} & JUMLAH & $\%$ \\
\hline 1. & 1 tahun & 4 & 13,3 \\
\hline 2. & 2 tahun & 11 & 36,67 \\
\hline 3. & 3 tahun & 10 & 33,33 \\
\hline 4. & Lebih dari 3 tahun & 5 & 16,67 \\
\hline & \multicolumn{2}{|c|}{} & 100 \\
\hline
\end{tabular}

\section{Sumber : data primer}

Tabel 1, menunjukkan bahwa mereka sudah lama mengenal Instagram yang ditunjukkan bahwa 70 prosen dari subjek penelitian telah mengenal dan menggunakan Instagram. Merujuk pada tahun 2014 sebagai awal boomingnya Instagram di Indonesia adalah seiring dengan perkembangan keremajaan para subjek penelitian yang saat itu yang usianya antara 12 hingga 13 tahun.

Para remaja yang menjadi subjek penelitian umumnya mengenal Instagram dari saudara dekat dan teman-teman mereka. Sehingga dapat dilihat disini bahwa para remaja mengenal Instagram melalui proses interaksi yang tentunya berujung kepada sosialisasi. Oleh karena itu maka istilah "digital native" pada remaja kelahiran pasca tahun 1996 kurang mengena dalam konteks ini dikarenakan para remaja bukan begitu saja mampu menggunakan media sosial Instagram melainkan melalui proses sosialisasi yang berlangsung dalam bentuk interaksi.

Sosialisasi Instagram sendiri mudah terjadi di kalangan remaja mengingat Instagram adalah media sosial ber-platform telepon seluler. remaja. Hal inilah yang kemudian menjadi salah satu faktor semakin mudahnya sosialisasi penggunaan Instagram di kalangan remaja.

Durasi dalam penggunaan Instagram oleh remaja sebagai subjek penelitian umumnya memerlukan waktu dari 2 jam. Oleh karena itu rata-rata remaja sebagai subjek dalam penelitian ini tergolong heavly user atau pengguna berat. Durasi penggunaan media sosial Instagram tersebut umumnya digunakan untuk media komunikasi dan presentasi diri. Durasi penggunaan yang dimaksud adalah 2 jam lebih dari 16 jam waktu untuk beraktifitas selama satu hari. Fenomena ini menunjukkan bahwa remaja selalu terkoneksi secara daring (online) melalui media sosial Instagram baik untuk berkomunikasi ataupun melakukan presentasi dan ekspresi diri. Bila diperbandingkan secara hitungan menit maka perilaku penggunaan Instagram oleh remaja subjek penelitian adalah rata-rata setiap 8 menit melakukan akses ke media sosial Instagram.

Setiap akses yang dilakukan remaja subjek penelitian adalah melakukan aktivitas mengecek tanggapan dari postingan foto mereka, 
atau melakukan aktivitas pengunggahan foto sebagai visualisasi simbol diri mereka. Aktivitas akses lain yang dilakukan oleh remaja subjek penelitian adalah melakukan direct message (DM) pesan langsung untuk berkomunikasi dengan pengguna lain yang menjadi followers mereka yang bertema tentang persoalan seharihari mereka.

Temuan lain yang menarik dari hasil penelitian ini adalah semua remaja sebagai subjek penelitian menggunakan identitas asli dalam akun Instagram mereka. Mereka justru tidak menyukai penggunaan identitas karena berpengaruh pada identitas branding bagi mereka. Selain itu alasan menggunakan identitas asli adalah karena remaja subjek penelitian lebih nyaman dengan identitas asli mereka tanpa perlu menggunakan nama samaran atau alias di akun Instagram. Menggunakan identitas asli, remaja subjek penelitian akan mudah dikenali oleh pengguna lain. Pada sisi lain remaja subjek penelitian menginginkan kejujuran dalam ekspresi maupun presentasi diri mereka agar dapat mendapatkan tanggapan positif dalam bentuk like dan comment dari pengguna lain yang menjadi followers.

Tanggapan positif yang dimaksudkan merupakan tanggapan atas unggahan foto ekspresi yang dilakukan remaja. Dari sumber data primer diperoleh fakta bahwa remaja subjek penelitian lebih dominan mengunggah foto dalam bentuk selfie (swafoto). Unggahan yang berbentuk foto selfie tersebut berhubungan dengan identitas asli yang digunakan oleh remaja sebagai subjek penelitian. Swafoto merupakan ekspresi spontan yang ditunjukkan berkaitan situasi diri remaja untuk menyampaikan suatu pesan menggunakan diri mereka beserta atributnya. Oleh karena itu jika identias palsu digunakan sementara selfie sebagai bagian pesan berbeda akan dianggap sebagai fake yang justru akan mendapatkan respon negatif dari para pengguna lain yang menjadi followersnya.

Pengunggahan foto selfie yang dilakukan remaja subjek penelitian lebih berorientasi sebagai cara menunjukkan eksistensi mereka dalam bentuk ekspresi diri tentang apa yang mereka lakukan. Artinya disini bahwa remaja sebagai pengguna Instagram melakukan presentasi diri dengan menunjukkan aktivitas mereka sebagai simbol identitas diri dihadapan para folllowers. Kecenderungan tersebut juga similar dengan unggahan foto-foto mereka dalam kategori lain seperti foto groufie, lanscape dan activites serta random. Semua jenis kategori diekspresikan untuk merepresentasikan identitas diri mereka melalui simbol yang melekat dalam diri mereka dan di luar diri mereka.

Secara sudut pandang psikologis presentasi remaja melalui kategori unggahan foto lebih ditujukan untuk menunjukkan identitas diri mereka. Instagram sebagai media sosial yang menonjolkan foto dan video (simbol visual) mampu digunakan remaja untuk membandingkan diri mereka yang realistis dengan versi foto sebagai bentuk visualisasi diri yang tidak realistis. Remaja subjek penelitian dapat memanipulasi visualisasi diri mereka bahkan dapat juga membuat identitas diri baru yang digunakan sebagai presentasi diri mereka

Tabel 2.

Penggunaan Media Sosial Instagram

\begin{tabular}{|l|l|c|c|}
\hline NO & LAMA KEPEMILIKAN AKUN & JUMLAH & $\mathbf{\%}$ \\
\hline 1. & Selfie & 13 & 43,3 \\
\hline 2. & Groufie & 4 & 13.3 \\
\hline 3. & Pemandangan dan Wisata & 5 & 16.7 \\
\hline 4. & Moment activities & 3 & 10 \\
\hline 5. & Foto Random & 5 & 16.7 \\
\hline & \multicolumn{2}{|c|}{} \\
\hline
\end{tabular}

\section{Sumber : data primer}


dihadapan orang lain khususnya para followers. Alasan yang dominan para remaja merasa nyaman dengan cara visualisasi diri bahkan membuat identitas baru karena mereka menganggap media sosial Instagram mampu memenuhi aktualisasi diri mereka melalui moment-moment yang mereka anggap penting serta dapat dengan mudah di share (dibagikan) pada pengguna lain untuk mendapatkan pengakuan secara instant melalui comment dan like.

Fakta-fakta hasil penelitian di atas menggarisbawahi bahwa terdapat perbedaan praktek budaya antara fotografi tradisional dengan fotografi menggunakan media sosial Instagram. Menggunakan logika Bourdieu (1996), praktik fotografi tradisional didasarkan pada kepemilikan kamera untuk menghasilkan foto sebagai ritual domestik yang diabadikan dan disimpan dalam album foto untuk tujuan mengingat kembali momen-momen tertentu. Sedangkan praktik fotografi pada Instagram tidak lagi didasarkan pada kepemilikan kamera, namun multi media dalam hal ini diwakili oleh telepon seluler (ponsel) atau gawai.

Gawai ataupun ponsel merubah bentuk komunikasi dan interaksi remaja subjek penelitian melalui perilaku keseharian yang selalu membutuhkan perangkat tersebut. Remaja subjek penelitian menjadikan gawai/ponsel sebagai media pokok dan gaya hidup yang dibutuhkan dalam perilaku sehari-hari khususnya dalam perolehan informasi dan memproduksi informasi. Salah satu produk informasi adalah unggahan foto yang digunakan untuk menyampaikan informasi dengan dominansi informasi seputar diri remaja.

Ponsel atau gawai sebagai alat utama Instagram telah merubah pratik fotografi yang rumit menjadi pratek fotografi yang mudah yaitu take, edit, and share dalam mereplikasi suatu peristiwa atau objek. Walaupun demikian penggunaan media sosial Instagram dengan alat utama ponsel/gawai tetap tidak mampu secara signifikan menghilangkan diterminisme kelas. Kepemilikan ponsel di kalangan remaja subjek penelitian juga menyisakan adanya perbedaan kelas, pemilihan berbagai ponsel/gawai yang menyatu dengan kamera serta pertimbangan kualitas untuk pemilihan foto beserta situasional objek yang di foto beserta lingkungan yang akan diunggah menunjukkan adanya perbedaan kelas.

Praktek memotret melalui pesan visual (foto) pada Instagram memberikan kemudahan dan tanpa keterampilan khusus bagi remaja pengguna. Artinya Instagram menghilangkan edukasi dalam penggunaanya tidak seperti praktek fotografi tradisional. Instagram yang mengutamakan penerbitan instan dengan menekankan sifat mobile sehingga mendekatkan dan memudahkan praktik fotografi dan menjadi menjadi praktik budaya yang melekat dalam keseharian remaja.

Praktek mengunggah foto sebagai simbol visual oleh remaja subjek penelitian memang mengarah kepada budaya visual yaitu mengarahkan pada vusialisasi peristiwa yang diberi makna untuk mendapatkan kesenangan berupa penghargaan atas presentasi diri mereka melalui keterhubungan mereka pada teknologi instagram sebagai media sosial. Dominansi pada unggahan foto selfie mengukuhkan jika remaja memang berusaha untuk menvisualisasikan suatu keberadaan (eksistensi) diri mereka dengan membuat visualisasi yang lebih mudah dipahami, ditampikan secara cepat dan menimbulkan rasa kesenangan akan visualisasi foto yang diunggah tersebut.

Dengan demikin maka model dan pola CMC dalam pembentukkan budaya visual adalah sebagai berikut : 


\section{Gambar 1. Model dan pola CMC remaja dalam membentuk budaya visual}

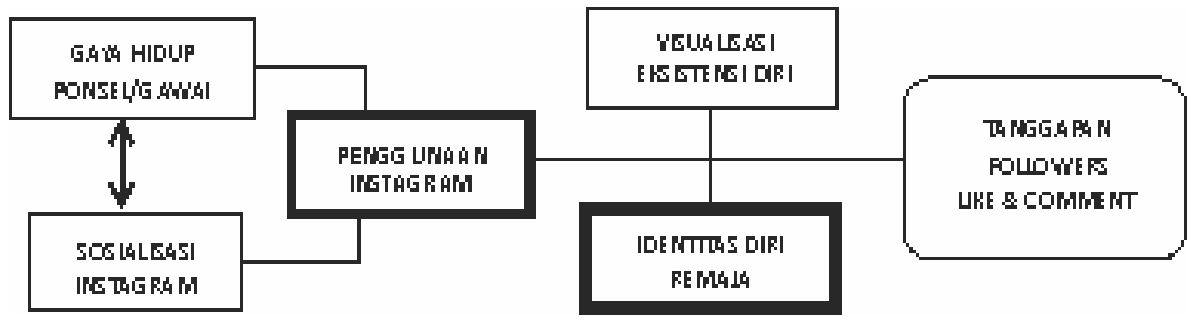

\section{Simpulan}

Budaya visual yang dilakukan remaja melalui media sosial Instgaram adalah merupakan bagian dari gaya hidup dalam penggunaan teknologi komunikasi berupa ponsel/gawai yang terjadi melalui ruang sosialisasi interaksi di kalangan remaja dengan lingkungannya. Media sosial Instagram selain merubah pola komunikasi dan interaksi remaja juga membudayakan remaja untuk menunjukkan eksistensi dan presentasi diri mereka melalui unggahan foto.

Unggahan foto dalam Instagram sebagai representasi eksistensi dan presentasi diri remaja yang lebih dominan digunakan untuk orientasi identitas diri mereka. Foto dalam Instagram sebagai simbol digunakan untuk menunjukkan diri remaja dalam kehidupan nyata serta manipulasi diri mereka secara virtual yang secara positif menginginkan tanggapan akan pengakuan identitas diri mereka dihadapan pengguna lain sebagai followers. Oleh karena itu budaya visual yang dilakukan remaja melalui unggahan foto dalam Instagram merupakan upaya remaja menvisualisasikan keberadaan/ eksistensi identitas diri mereka dalam konteks moment tertentu dan kesenangan tertentu.

Saran yang diberikan dalam penelitian ini adalah literasi media sosial perlu diberikan kepada remaja sebagai digital natives agar mampu beretika dalam bermedia sosial serta terhindar dari dampak negatif penggunaan media sosial seperrti kejahatan cyber, net bullying atau perilaku kriminal lainnya.

\section{Daftar Pustaka}

Bourdieu, Pierre , 1996, Photography: A Middle-Brow Art Paperback - March
1, 1996, Stanford University Press

De Certeau, Michelle, 1984, The Practice of every Day Life, Berkely, Los Angeles

Green, W, Lawrence.et.al, 2005, Health Education Planing A Diagnostik Approach, The Johns Hapkins University: Mayfield Publishing Company, 2005 Heidegger, Martin, 1977, The Origin The Work of Art, Garlad Publishing Knapp, ML, JA Dally, 2010, Handbook Of Interpersonal Communication, Sage Publication Mitchell, WJT, 1994, Iconology: Image, Text, Ideology, Chicago: $\mathrm{U}$ of Chicago $\mathrm{P}$ Mirzoeff, Nicholas (ed.), 2002, The Visual Culture Reader, second edition, London\&New York:Routledge

Martin, Judith, Thomas Nakayama, 2003, Interculture Communication in Context, US, McGraw Hill Companies Saukko, Paula, 2003, Doing Research in Cultural Studies, London, Sage Publication Spradley, James, 2016, The Ethnographic Interview. Belmont, CA: Wadsworth. Thurlow, Crispin etc, 2007, Computer Mediated Communication, Sage Publications, California Walther,J.B.,\&Jang,J.-W.,2009,Communication Processes In Participatory Web Sites. Journal of ComputerMediated Communication, 18, 2-15. doi:10.1111/j.1083-6101.2012.01592.x

\section{Internet}

http://sp.beritasatu.com/inovasi/popularitasfacebook-kian-meredup/72551 tgl 22 Desember 2014 diakses tanggal 21 Januari 2015 
http://kominfo.go.id/index.php/content/ detail/3834/Siaran+Pers+No.+17-PIHKOMINFO-2- diakses 25 Januari 2015

(http://www.infospesial.net/40137/bosandengan-facebook-banyak-remaja-beralih-keinstagram/?mobile $=0$ tgl 9 Oktober 2014

http://www.republika.co.id/berita/trendtek/ aplikasi/14/01/01/mypdh6-instagram-bakalgeser-posisi-twitter 1 januari 2015 diakses tangal 12 Maret 2015 